\title{
Testing carrier status in siblings of patients with cystic fibrosis
}

\author{
Ian Balfour-Lynn, Su Madge, Robert Dinwiddie
}

\begin{abstract}
Altogether 114 parents of patients attending a cystic fibrosis clinic and 27 regional genetics units were surveyed for their views on whether healthy siblings should be tested for carrier status during childhood. Most parents wanted to know their child's carrier status and felt it was their right; almost all would tell the children if they were carriers. However, $37 \%$ of the units never tested siblings and $40 \%$ said the parents had no right to this knowledge. Furthermore, $60 \%$ would withhold the information from parents.

(Arch Dis Child 1995; 72: 167-168)
\end{abstract}

Keywords: cystic fibrosis, screening, carrier state.

Unaffected siblings of children with cystic fibrosis have a two in three chance of being carriers of the recessive gene. Depending on the genotype of the index case, it is often possible to determine the carrier status of these siblings. Although there is agreement that carrier testing should be offered to families of patients with cystic fibrosis, opinions vary as to whether this should be performed on children too young to be involved in the decision. The recent report from the Clinical Genetics Society (UK) was not in favour of testing children for recessive disorders that was of purely reproductive significance to that child in the future. ${ }^{1}$ This study was designed to elicit the views of parents of children with cystic fibrosis over this issue.

Respiratory Unit, Great Ormond Street Hospital for Childre NHS Trust, Great Ormond Street, London WC1N 3JH

I Balfour-Lynn

S Madge

$R$ Dinwiddie

Correspondence to:

Dr Balfour-Lynn.

Accepted 14 November 1994

\section{Methods}

Parents of patients with cystic fibrosis attending the cystic fibrosis clinic at Great Ormond Street Hospital for Children were approached directly and asked to fill in a questionnaire. A separate questionnaire was sent to the heads of department of the 30 regional genetics services listed in the Cystic Fibrosis Trust booklet entitled Genetics, carrier tests and tests during pregnancy.

\section{Results}

Parents of 115 children were approached and 114 agreed to fill in the questionnaire (113 parents, one grandparent). The one refusal was from a father who was thought to have difficulty reading. Ninety eight per cent understood the term 'cystic fibrosis carrier' and 86\% had thought about the issue of carrier testing before. Of those who had other children $(n=102), 33 \%$ already knew the siblings' carrier status. Results from parents are shown in tables 1 and 2. Parents were also asked who had the most rights over knowledge of a child's carrier status: $11 \%$ thought the parents, $14 \%$ the child, $67 \%$ that parents and child had equal rights, $2 \%$ thought doctors, $3 \%$ were unsure, and 5\% didn't answer.

Out of 30 genetics units contacted, replies were received from 27 (90\% response rate); 10 units $(37 \%)$ never tested siblings and 17 units $(63 \%)$ did. Most units only tested after formal counselling and the impression given was that they would try to dissuade the parents or postpone testing until the child was older. The majority could not answer the questions without many additional comments; a representation of their views is given within the discussion section.

Table 1 Results of parents' questionnaire (\%)

\begin{tabular}{|c|c|c|c|c|c|}
\hline & Yes & No & Unsure & $\begin{array}{l}\text { Not } \\
\text { applicable }\end{array}$ & $\begin{array}{l}\text { Did not } \\
\text { answer }\end{array}$ \\
\hline $\begin{array}{l}\text { If the facility was available would you like to know the } \\
\text { carrier status of your other children or children you } \\
\text { may have in the future? }\end{array}$ & 90 & 2 & 4 & 4 & 0 \\
\hline $\begin{array}{l}\text { Do you think you have a right to know the carrier status } \\
\text { of any children you have or may have in the future? }\end{array}$ & 91 & 2 & 4 & 1 & 2 \\
\hline $\begin{array}{l}\text { If you knew, would you tell your children that they are } \\
\text { carriers of cystic fibrosis? }\end{array}$ & 96 & 0 & 4 & 0 & 0 \\
\hline $\begin{array}{l}\text { Do you think your child wants to know his carrier status? } \\
\text { Has your child ever asked? }\end{array}$ & $\begin{array}{l}61 \\
38\end{array}$ & $\begin{array}{r}2 \\
29\end{array}$ & $\begin{array}{r}11 \\
1\end{array}$ & $\begin{array}{l}23 \\
25\end{array}$ & $\begin{array}{l}3 \\
8\end{array}$ \\
\hline $\begin{array}{l}\text { Would knowledge of your child's carrier status affect the } \\
\text { way you brought him up? }\end{array}$ & 10 & 85 & 1 & 0 & 4 \\
\hline $\begin{array}{l}\text { Would you arrange for the test to be done without telling } \\
\text { the child what the test was for? }\end{array}$ & 10 & 84 & 2 & 0 & 4 \\
\hline $\begin{array}{l}\text { If the child said he did not want to know his carrier } \\
\text { status would you still go ahead with the test? }\end{array}$ & 40 & 39 & 14 & 6 & 0 \\
\hline $\begin{array}{l}\text { If the hospital knew the carrier status of your child, } \\
\text { should they automatically tell you if you request the } \\
\text { information? }\end{array}$ & 95 & 2 & 0 & 0 & 4 \\
\hline
\end{tabular}

\section{Discussion}

It would appear from these findings that the parents of children with cystic fibrosis have a different viewpoint over testing the carrier status of their unaffected children from that put forward by the Clinical Genetics Society ${ }^{1}$ and most clinical geneticists we surveyed.

\section{WHY PARENTS WANT TO KNOW}

The vast majority of parents wanted to know the carrier status of their other children, and a third had already found out. This study did not ascertain their reasons, but in the case of the younger children, it is likely that it was simply for the sake of knowing. Knowledge of carrier status offers no advantage to the children as there is no risk to health from being a cystic fibrosis carrier. Information on carrier status is primarily important for informed reproductive decision making, which is not relevant until mid to late teens. Perhaps many parents feel that as they will eventually know the answer, 
Table 2 Ages children asked and when parents would tell them if they were cystic fibrosis carriers

\begin{tabular}{llllllllll}
\hline & \multicolumn{3}{c}{ Age (years) } & & & Not & $\begin{array}{c}\text { Did not } \\
\text { applicable }\end{array}$ \\
\cline { 2 - 7 } & $<5$ & $5-9$ & $10-15$ & $>15$ & Unsurer \\
\hline $\begin{array}{c}\text { If you would tell your children they } \\
\text { are carriers, at what age would } \\
\text { you do so? }\end{array}$ & 5 & 20 & 45 & 24 & 1 & 0 & 5 \\
$\begin{array}{c}\text { If your child asked whether he was a } \\
\text { carrier, at what age did he do so? }\end{array}$ & 1 & 14 & 15 & 6 & 0 & 54 & 10 \\
\hline
\end{tabular}

they might as well find out sooner. Seventy nine per cent of parents (in whom this question was applicable) thought the children themselves wanted to know their carrier status; this is not surprising considering the children belong to a family where the consequences of having a child with cystic fibrosis are only too evident.

\section{CAN CARRIER TESTING BE HARMFUL?}

One argument against testing siblings is that it would affect the way parents brought up the children if they knew they were carriers, and half the geneticists believed this to be the case. However, $85 \%$ of the parents said it would not affect the child's upbringing. This is not surprising as, by definition, the parents themselves are carriers and realise that before the burden of caring for a child with cystic fibrosis, there was no effect on their own health or well being. Furthermore it is most unlikely there would be stigmatisation within the families.

Experience with other inherited conditions has shown that knowledge of carrier status may sometimes be disadvantageous. In the past, screening for sickle cell trait and haemoglobinopathies has led to stigmatisation which produced problems with health insurance, employment, and even marriage prospects. ${ }^{2}$ In the case of cystic fibrosis, it is unlikely this would be a problem although insurance companies may treat carriers less favourably.

A recent study on cystic fibrosis carrier screening in adults has looked at the consequences of being diagnosed as a carrier. ${ }^{3}$ It was found that the usual initial response was one of surprise and slight anxiety or worry; six months later $27 \%$ still reported feelings of slight anxiety, and only two out of 60 subjects felt worried or depressed. However, only $6 \%$ of carriers regretted being tested, and furthermore, carriers told their partners, family and friends, and did not seem to feel stigmatised. The issue of cystic fibrosis carrier testing has also been looked at in teenagers. In a group of over 800 schoolchildren aged $15-17$ years who had been part of a cystic fibrosis screening programme, none of the identified carriers thought their carrier status had harmed their own health and self image was not affected. Although almost half experienced a degree of anxiety on receiving the result, none felt anxious on counselling 1-2 weeks later. ${ }^{4}$

\section{OWNERSHIP AND CONTROL OF GENETIC}

\section{INFORMATION}

Another important and difficult issue is ownership of genetic information, namely who has rights over knowledge of a person's genotype.
Most parents felt they had a right to know their child's carrier status within the context that two thirds thought that parents and child had equal rights to this knowledge. In contrast, $40 \%$ of geneticists said parents had no right at all and almost half the geneticists said the hospital need not automatically tell parents the results, even if requested. Furthermore, $60 \%$ would not inform parents if they knew the child to be a carrier after testing for the homozygous state. We feel it is wrong for the medical profession to withhold information of this nature from the family and no parent said they would withhold information from their child.

It is a fundamental right to have knowledge about one's own health and it ought to be an equal right to be able to refuse testing. This could pose a problem as $40 \%$ of the parents would go ahead with carrier testing even if the child did not wish to know his own status (although only one geneticist said they would agree to this). Good practice would make it prudent for children to be involved in any decision about testing their genotype, particularly when the test could be delayed until they are old enough to express an opinion. Some siblings might simply not want to know their carrier status and previous work has shown that not all relatives of a cystic fibrosis sufferer want to be tested. ${ }^{5}$

\section{Conclusion}

In conclusion, we have reported this study in order to stimulate further debate, particularly among clinicians looking after children with cystic fibrosis and their families. We have not said whether one side is right or wrong. It is unlikely that a consensus can be reached but each family must be taken on its own merit. As with many difficult ethical issues in clinical paediatrics, the problem still remains as to who should be making these sorts of decisions. Clearly it is important to involve all parties in the discussion and informed pretest counselling is obligatory. Although it may be prudent to wait until the child is old enough to make the decision, problems arise when parents of younger children are insistent. Determined parents will only go elsewhere to have the test done and it is likely that commercial pressures will eventually make genetic testing available both in private laboratories and from the local chemist (see a report in the Daily Express (8/8/94) entitled ' $£ 25$ DIY test to check for deadly genes'). Further discussion of these issues is now vital.

We wish to thank all the parents and geneticists who participated in this study.

1 Clinical Genetics Society (UK). The genetic testing of children. Report of a Working Party of the Clinical children. Report of a Working Party of the Clinical 2 Wilfond BS, Fost N. The cystic fibrosis gene: medical and social implications for heterozygote detection. $\mathcal{F} A M A$ 1990; 263: 2777-83

3 Watson EK, Mayall ES, Lamb J, Chapple J, Williamson R. Psychological and social consequences of community carrier screening programme for cystic fibrosis. Lancet 1992; 340: 217-20.

4 Mitchell J, Scriver CR, Clow CL, Kaplan F. What young people think and do when the option for cystic fibrosis carrier testing is available. 7 Med Genet 1993; 30: 538-42.

5 Watson EK, Williamson R, Chapple J. Attitudes to carrier screening for cystic fibrosis: a survey of health care professcreening for cystic fibrosis: a survey of health care profespublic. Br ₹ Gen Pract 1991; 41: 237-40. 